\title{
Erigeron Witches'-Broom Phytoplasma in Brazil Represents New Subgroup VII-B in 16S rRNA Gene Group VII, the Ash Yellows Phytoplasma Group
}

Thereza S. L. Barros, USDA-ARS, Molecular Plant Pathology Laboratory, Beltsville, MD 20705, USA, and Laboratório de Virologia e Microscopia Eletrônica, Departamento de Biologia Celular, Universidade de Brasília, Brasília, DF, 70919-970, Brazil; Robert E. Davis, USDA-ARS, Molecular Plant Pathology Laboratory, Beltsville, MD; Renato O. Resende, Laboratorio de Virologia e Microscopia Eletrônica, Departamento de Biologia Celular, Universidade de Brasília, Brasília, DF, 70919-970, Brazil; and Ellen L. Dally, USDA-ARS, Molecular Plant Pathology Laboratory, Beltsville, MD

\begin{abstract}
Barros, T. S. L., Davis, R. E., Resende, R. O., and Dally, E. L. 2002. Erigeron witches'-broom phytoplasma in Brazil represents new subgroup VII-B in 16S rRNA gene group VII, the ash yellows phytoplasma group. Plant Dis. 86:1142-1148.

A previously undescribed phytoplasma, Erigeron witches'-broom phytoplasma, was detected in diseased plants of Erigeron sp. and Catharanthus roseus exhibiting symptoms of witches'broom and chlorosis in the state of São Paulo, Brazil. On the basis of restriction fragment length polymorphism (RFLP) analysis of $16 \mathrm{~S}$ rDNA amplified in the polymerase chain reaction (PCR), Erigeron witches'-broom phytoplasma was classified in group 16SrVII (ash yellows phytoplasma group), new subgroup VII-B. Phylogenetic analysis of 16S rDNA sequences indicated that this phytoplasma represents a new lineage that is distinct from that of described strains of ash yellows phytoplasma. Erigeron witches'-broom phytoplasma is the first member of the ash yellows phytoplasma group to be recorded in Brazil.
\end{abstract}

Additional keywords: MLO, mycoplasmalike organism, phylogeny
Phytoplasmas (previously mycoplasmalike organisms [MLOs]) are unique cellwall-less, prokaryotic pathogens of plants (17). Because it has not been possible to isolate and characterize any phytoplasma in pure culture in vitro, the detection and identification of phytoplasmas was long based upon biological characteristics of the pathogens and associated plant diseases (17). Molecular methods afforded new approaches that have led to discoveries of diverse phytoplasmas and to the construction of a comprehensive scheme for phytoplasma identification and classification. On the basis of restriction fragment length polymorphism (RFLP) analyses of $16 \mathrm{~S}$ rDNA, phytoplasmas have been classified into groups and subgroups, each distinct group representing at least one putative phytoplasma species $(13,17,18,22)$. Phylogenetic analyses have revealed that phytoplasmas descended from gram-positive

Corresponding author: Robert E. Davis

E-mail: davisr@ba.ars.usda.gov

GenBank Accession numbers of DNA sequences: AY034608, AF411592

Accepted for publication 23 May 2002.

Publication no. D-2002-0815-01R

This article is in the public domain and not copyrightable. It may be freely reprinted with customary crediting of the source. The American Phytopathological Society, 2002. bacterial ancestors and form a monophyletic clade in the class Mollicutes $(13,20,24,29,30)$. New understanding of phytoplasma diversity and phylogenetic relationships, the discovery of diverse phytoplasma lineages, and a provisional taxonomy involving descriptions of "Candidatus Phytoplasma species" have emerged from applications of molecular methods $(6,11,22,28,35,36)$.

In South America, phytoplasmas belonging to four major groups (groups 16SrI, $16 \mathrm{SrIII}, 16 \mathrm{SrIX}$, and $16 \mathrm{SrXV}$, respectively), representing at least four putative species, have been characterized $(1,3,7,22,23)$. Phytoplasmas in South America that belong to group 16SrIII (X-disease phytoplasma group) and group $16 \mathrm{SrXV}$ (hibiscus witches'-broom phytoplasma group) are distinct from phytoplasmas described elsewhere, and hibiscus witches'-broom phytoplasma has been described as a distinct "Candidatus Phytoplasma species", "Ca. P. brasiliense" $(22,23)$. Previously we hypothesized that unique ecology and geographic separation provided conditions favorable for the divergence, in South America, of phytoplasma lineages from those found in other regions of the world
Table 1. GenBank accession numbers of phytoplasmal and Acholeplasma laidlawii 16S rRNA gene sequences used in this study

\begin{tabular}{ll}
\hline Phytoplasma (strain) & Accession no. \\
\hline Erigeron witches'-broom (EriWB) & AY034608 \\
Rio das Pedras witches'-broom (RPWB) & AF411592 \\
Apple proliferation (AT) & X68375 \\
Aster yellows (AY) & AF322644 \\
Bermuda grass white leaf (BGWL) & AF248961 \\
Brinjal little leaf (BLL) & X83431 \\
"Candidatus Phytoplasma australiense" (AUSGY) & L76427 \\
"Ca. P. brasiliense" (HibWB) & AF147708 \\
"Ca. P. fraxini”" (ash yellows, AshY1T) & AF09209 \\
"Ca. P. fraxini", (ash yellows, AshY3) & AF105315 \\
"Ca. P. fraxini” (ash yellows, AshY5) & AF105316 \\
"Ca. P. fraxini" (lilac witches'-broom, LWB3) & AF105317 \\
"Ca. P. aurantifolia" (LimeWB) & U15442 \\
"Ca. P. japonicum" & AB010425 \\
Clover phyllody (CPh) & AF222065 \\
Clover proliferation (CP) & L33761 \\
Clover yellow edge (CYE-C) & AF175304 \\
Coconut lethal yellows (LY) & U18747 \\
Elm yellows (EY1) & AF122910 \\
Loofah witches'-broom (LfWB) & AF248956 \\
Mexican periwinkle virescence (MPV) & AF248960 \\
"Fragaria multicipita" phytoplasma (MC) & AF190224 \\
Peanut witches'-broom (PnWB) & L33765 \\
Pigeon pea witches'-broom (PPWB) & U18763 \\
Rice yellow dwarf (RYD) & D12581 \\
Stolbur (STOL) & X76427 \\
Tomato big bud (BB) & AF222064 \\
Western X-disease (WX) & L04682 \\
Acholeplasma laidlawii & M23932 \\
\hline & \\
&
\end{tabular}


(22). The results of the present study support this hypothesis and provide new knowledge about the diversity of phytoplasma lineages in South America. In this communication, we describe molecular characterization of a previously undescribed phytoplasma infecting Erigeron sp. in Brazil and report its phylogenetic relationship to phytoplasmas elsewhere, including its close relationship to a distinct phytoplasma group originally described in North America.

\section{MATERIALS AND METHODS}

Plant samples and reference phytoplasma strains. Symptomatic leaves of erigeron (Erigeron sp.) and periwinkle (Catharanthus roseus L. (G. Don)) were collected from naturally diseased plants exhibiting symptoms of witches'-broom disease in the state of São Paulo, Brazil. Ash yellows (AshY) phytoplasma strain AshY1 $1^{\mathrm{T}}$ (type strain of "Candidatus Phytoplasma fraxini" and member of group $16 \mathrm{SrVII})$ and clover proliferation phytoplasma strain CP (member of group 16SrVI) (kindly supplied by I.-M. Lee) were used as reference strains in direct comparisons of RFLP patterns of $16 \mathrm{~S}$ rDNA. The reference phytoplasmas were maintained by grafting in plants of $C$. roseus grown in an insect-proof greenhouse.

Amplification of DNA in the polymerase chain reaction (PCR). DNA for use as template in PCRs was extracted from symptomatic plant tissues as described previously by Prince et al. (27). The template DNA was further purified by the use of GeneCleanIII Kit (Q-BIOgene, Carlsbad, CA). Universal phytoplasma primer pairs, P1/P7 (33) and R16F2n/ R16R2 (F2n/R2) (12), were used to prime amplification of phytoplasma 16S rDNA (16S rRNA gene) sequences in nested PCR assays. Products of PCRs primed by P1/P7 were diluted 1:50 with HPLC grade water (Sigma-Aldrich, St. Louis, MO) and used as templates in PCRs primed by $\mathrm{F} 2 \mathrm{n} / \mathrm{R} 2$. All reactions were performed in $0.5-\mathrm{ml}$ PCR tubes, in a final volume of $50 \mu \mathrm{l}$ of reaction mixture, as previously described (6). PCRs were carried out for 35 cycles using the following conditions: $1 \mathrm{~min}(3$ min for first cycle) denaturation at $94^{\circ} \mathrm{C}$, annealing for $2 \mathrm{~min}$ at $55^{\circ} \mathrm{C}$, and primer extension for $3 \mathrm{~min}$ (10 $\mathrm{min}$ in final cycle) at $72^{\circ} \mathrm{C}$. Negative controls consisted of reaction mixtures devoid of templates. PCR products were analyzed by electrophoresis through $1 \%$ agarose gel, staining with ethidium bromide, and visualization of DNA bands using a UV transilluminator. The DNA fragment size standard used was 1-kb ladder (Invitrogen/Life Technologies, Gaithersburg, MD).

RFLP analyses of amplified phytoplasma DNA. Products from the nested PCRs primed by F2n/R2 were analyzed by single restriction endonuclease digestion with AluI, HhaI, and KpnI (Invitrogen/Life Technologies), and with BfaI, HaeIII, HinfI, HpaII, MseI, RsaI, Sau3AI, TaqI, and ThaI (New England BioLabs, Beverly, MA), following instructions by the manufacturers. The products of digestion were analyzed by electrophoresis through a $5 \%$ polyacrylamide gel followed by staining with ethidium bromide and visualization of DNA bands with a UV transilluminator. The DNA fragment size standard used was a PhiX174 RF HaeIII digest (Invitrogen/Life Technologies). The RFLP patterns of phytoplasma DNAs were compared with the RFLP patterns previously published (18). Group affiliations are designated according to the classification system of Lee et al. $(18,19)$.

Cloning of PCR products and sequencing of DNA. Two phytoplasma DNA sequences, one from Erigeron sp. and one from $C$. roseus, that had been amplified in PCRs primed by $\mathrm{P} 1 / \mathrm{P} 7$ were cloned in Escherichia coli using the TOPO TA Cloning Kit (Invitrogen, Carlsbad, CA) according to manufacturer's instructions. Both strands of the cloned 1.8-kbp DNA fragments of rDNA were sequenced by use of automated DNA sequencing. The sequences were assembled after a minimum of $2 \times$ sequencing coverage for each base position. The nucleotide sequences deter- mined in this study were deposited in the GenBank data library (National Center for Biotechnology Information, National Library of Medicine, Bethesda, MD). Other phytoplasmal and Acholeplasma laidlawii $16 \mathrm{~S}$ rDNA sequences used in this study were obtained from GenBank (Table 1).

Sequence similarity, coefficient of similarity calculations, and putative restriction site analysis. The $16 \mathrm{~S}$ rDNA sequence similarities between strains were evaluated after alignments were generated by using the MegAlign option of DNASTAR program (DNASTAR, Inc., Madison, WI). Coefficients of similarity $(F)$ of $16 \mathrm{~S}$ rDNA were calculated on the basis of putative restriction site maps generated by using the DNASTAR program MapDraw option. $F$ was calculated, according to Nei and $\mathrm{Li}(25)$, as $F=2 N_{x y} /\left(N_{x}+N_{y}\right)$, where $x$ and $y$ are the strains of two given phytoplasmas, $N_{x}$ and $N_{y}$ are numbers of fragments resulting from digestion of $16 \mathrm{~S}$ rDNA by 12 enzymes in strains $x$ and $y$ respectively, and $N_{x y}$ is the number of fragments shared by the two strains.

Phylogenetic analysis. 16S rRNA gene sequences $(1.2 \mathrm{kbp}$ in size, representing the sequence between annealing sites of primer pair $\mathrm{F} 2 \mathrm{n} / \mathrm{R} 2$ ) from EriWB phytoplasma and 26 other phytoplasma strains representing fifteen $16 \mathrm{~S}$ rRNA phytoplasma
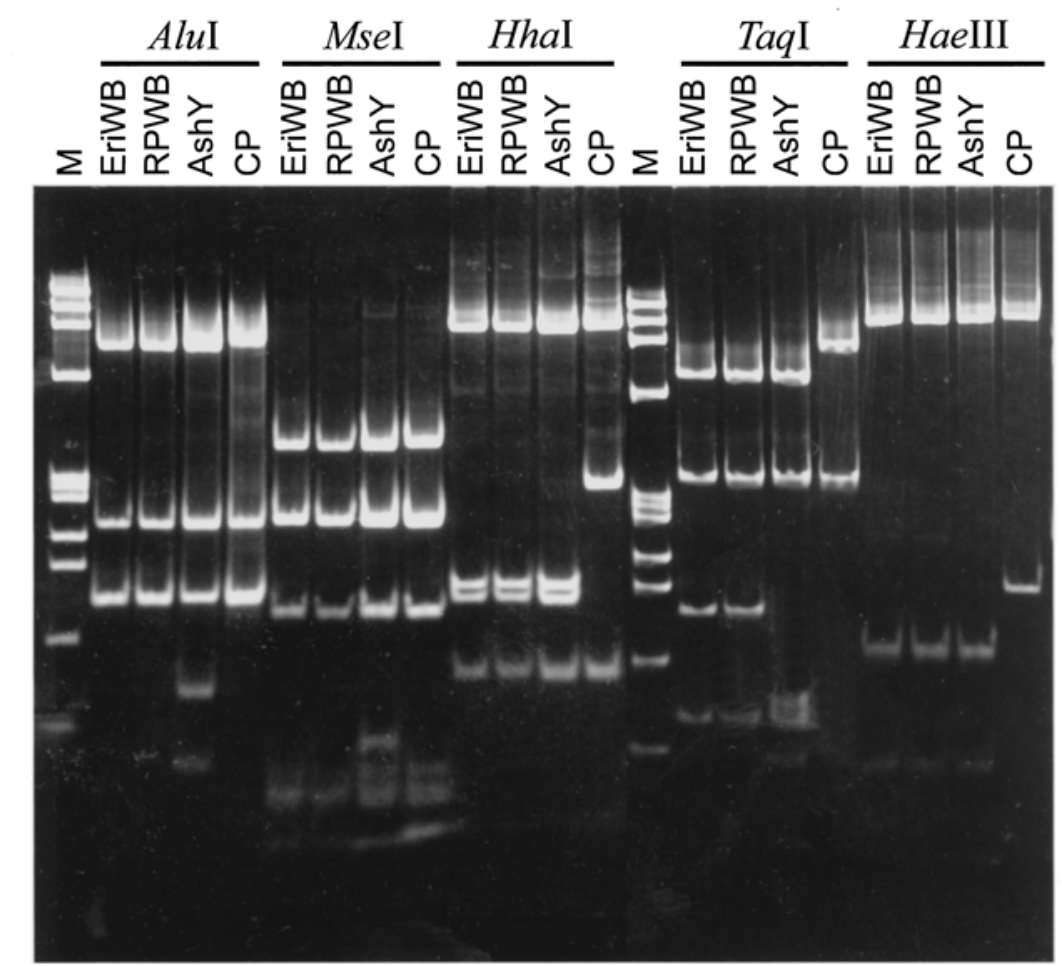

Fig. 1. Restriction fragment length polymorphism (RFLP) analysis of 16S rDNA amplified in nested polymerase chain reaction (PCR) primed by oligonucleotide pair F2n/R2 from Erigeron witches'broom phytoplasma strain EriWB infecting a naturally diseased plant of Erigeron sp. First round of PCR was primed by P1/P7, followed by reamplification of target DNA in nested PCR primed by F2n/R2. DNA products from the second (nested) PCR were digested with restriction endonucleases AluI, MseI, HhaI, HaeIII, and TaqI. M, Phi X174 HaeIII digest size standard. EriWB, Erigeron witches'-broom phytoplasma strain EriWB. RPWB, Erigeron witches'-broom phytoplasma strain RPWB. AshY, "Candidatus Phytoplasma fraxini" strain AshY1 ${ }^{\mathrm{T}}$. CP, clover proliferation phytoplasma. 
groups, and A. laidlawii were aligned using Clustal X version 1.63b (34). A phylogenetic tree was constructed by the NeighborJoining method of the Clustal X program, and the tree was viewed by using TreeViewPPC (26). A. laidlawii was selected as the outgroup to root the tree. Bootstrapping was performed 1,000 times for estimation of stability and support for the clades.

\section{RESULTS}

Phytoplasma detection and RFLP analyses. The diseased plants of erigeron and periwinkle exhibited symptoms typical of phytoplasmal infections, including re- duced size of leaves, chlorosis, and proliferation of axillary shoots resulting in prominent witches'-broom growths. Direct and nested PCRs primed by phytoplasma universal primer pair $F 2 n / R 2$ resulted in the amplification of 1.2-kbp DNA fragments, indicating that the symptomatic erigeron and periwinkle plants were infected by phytoplasma. The phytoplasma strains detected in erigeron and periwinkle were designated Erigeron witches'-broom phytoplasma (EriWB) and Rio das Pedras witches'broom phytoplasma (RPWB), respectively.

The detected phytoplasma strains were classified on the basis of RFLP analysis of
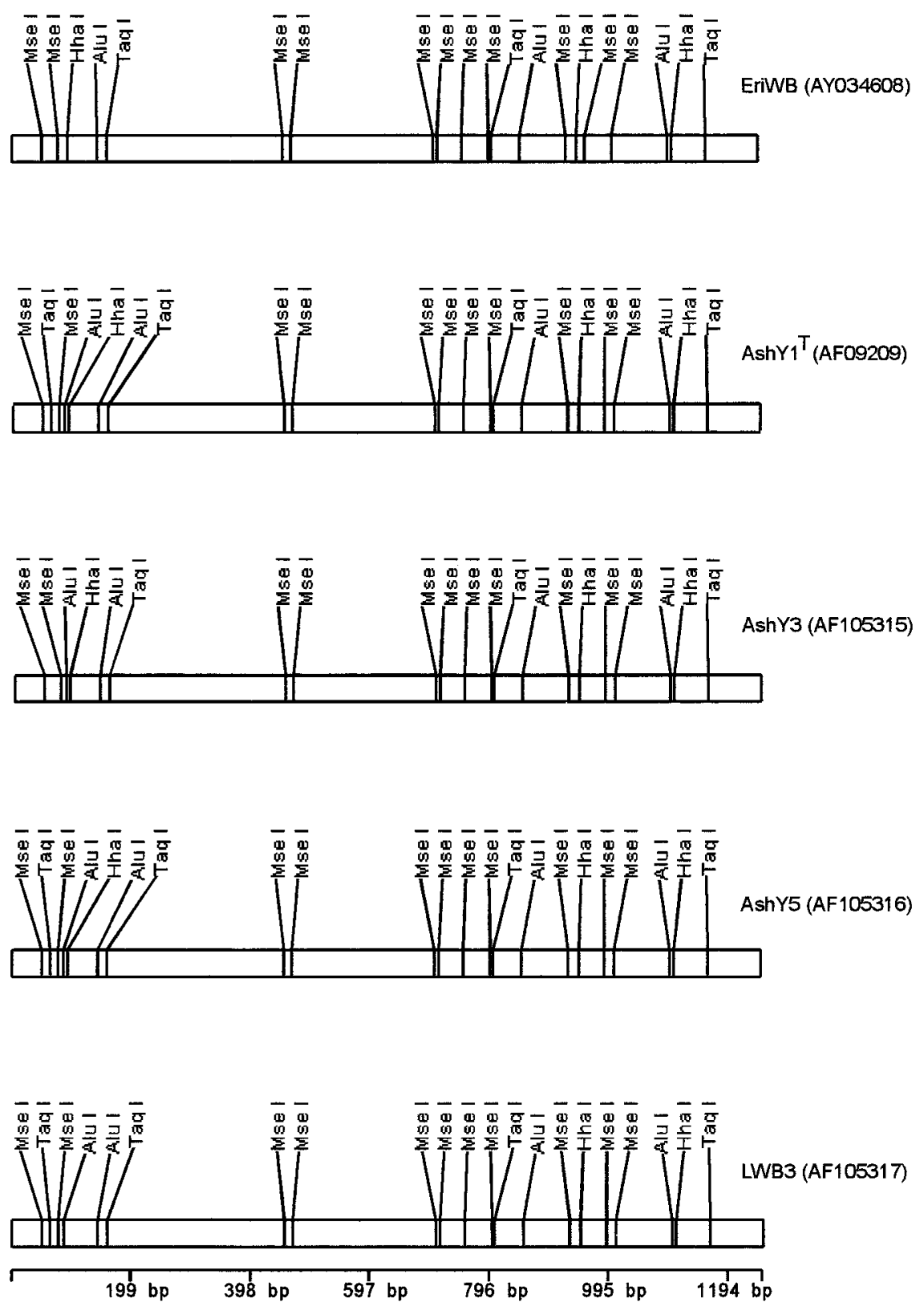

Fig. 2. Analysis of putative restriction sites in cloned 16S rDNA sequences from Erigeron witches'broom phytoplasma strain EriWB and ash yellows phytoplasma ("Candidatus Phytoplasma fraxini") strains AshY1 ${ }^{\mathrm{T}}$, AshY3, AshY5, and LWB3. GenBank numbers of the sequences are in parentheses. Each sequence represents that amplified in polymerase chain reaction (PCR) primed by oligonucleotide pair F2n/R2; phytoplasma classification into $16 \mathrm{~S}$ rDNA groups and subgroups is based upon restriction sites in this sequence.
16S rDNA amplified in PCR primed by primer pair $\mathrm{F} 2 \mathrm{n} / \mathrm{R} 2$, according to the classification scheme established by Lee et al. $(18,19)$. The collective RFLP patterns were compared with those published for other phytoplasmal $16 \mathrm{~S}$ rDNAs $(9,10,14,18,31)$. Strains EriWB and RPWB were indistinguishable from each other on the basis of collective RFLP patterns of rDNA from EriWB and RPWB (Fig. 1 and data not shown), consistent with the hypothesis that both plant species were infected by the same phytoplasma taxon. Based on these results, we tentatively consider EriWB and RPWB to be strains of a single phytoplasma taxon, Erigeron witches'-broom phytoplasma.

Based on the 12 RFLP profiles obtained, strains EriWB and RPWB are more closely related to groups $16 \mathrm{SrVI}$ (clover proliferation phytoplasma group, group VI) and 16SrVII (ash yellows phytoplasma group, group VII) than to other phytoplasma groups. EriWB and RPWB yielded $B f a \mathrm{I}$, HpaII, HinfI, KpnI, RsaI, Sau3AI, and ThaI RFLP patterns that were indistinguishable from those of ash yellows phytoplasma strain $\mathrm{AshY} 1^{\mathrm{T}}$ (type strain of " $\mathrm{Ca}$. $\mathrm{P}$. fraxini" and representative strain of group VII) and clover proliferation (CP) phytoplasma (representative of group VI) (data not shown). However, strains EriWB and RPWB were distinguished from CP and other previously described members of group VI by TaqI, HhaI, and HaeIII RFLP patterns and from group VII strain AshY $1^{\mathrm{T}}$ and other phytoplasmas by TaqI, MseI, and $A l u$ I RFLP patterns of $16 \mathrm{~S}$ rDNA (Fig. 1). The TaqI RFLP pattern of 16S rDNA from EriWB and RPWB appeared similar to that of rDNA from CelY phytoplasma, a member of group 16SrXII, subgroup A (stolbur phytoplasma subgroup). These results indicated that the Erigeron witches'-broom phytoplasma (strains EriWB and RPWB) was distinct from phytoplasmas described previously.

Putative restriction sites in $16 S$ rDNA. Nucleotide sequences determined for the cloned 1.8-kbp DNA fragments from Erigeron witches'-broom phytoplasma, strains EriWB and RPWB, were deposited in the GenBank database under accession numbers AY034608 and AF411592, respectively. Expected fragment sizes based on analysis of putative restriction sites were in excellent agreement with fragment sizes obtained by enzymatic RFLP analysis of amplified DNA. Putative restriction site analysis revealed the presence of unique sites in $16 \mathrm{~S}$ rDNA that distinguished EriWB phytoplasma from phytoplasmas previously described $(11,18)$ as members of group 16SrVII and strains $\left(\mathrm{AshY}^{\mathrm{T}}\right.$, AshY3, AshY5, and LWB3) of "Candidatus Phytoplasma fraxini” (Fig. 2). For example, strain EriWB differed from the "Ca. P. fraxini" strains by the absence in EriWB 16S rDNA of an AluI site that is present in the $16 \mathrm{~S}$ rDNA of the " $\mathrm{Ca}$. P. 
fraxini" strains, and by sites for MseI in different positions (Fig. 2). These restriction sites that distinguished EriWB from the "Ca. P. fraxini" strains were located within a region that corresponds to the 1.2kbp fragment that is amplified in PCR primed by primer pair $\mathrm{F} 2 \mathrm{n} / \mathrm{R} 2$ and is used for classification of phytoplasmas in the scheme of Lee et al. $(18,19)$.

Coefficients of similarity. Coefficients of similarity in RFLP patterns of $16 \mathrm{~S}$ rDNA were calculated using putative restriction site analysis of sequences corresponding to fragments amplified in PCRs primed by $F 2 n / R 2$. The coefficients of similarity between Erigeron witches'broom phytoplasma and two strains from group 16SrVI were 0.86 and 0.89 (Table 2 ), and the coefficient of similarities values between Erigeron witches'-broom phytoplasma and four strains previously classified in group 16SrVII ranged from 0.88 to 0.94 (Table 2). On the basis of these data, Erigeron witches'-broom phytoplasma was classified in group VII, new subgroup B (VII-B), because these values were within the range of coefficients of similarity reported (18) among strains within other groups.

Sequence similarity of $16 S$ rRNA genes. Strains EriWB and RPWB shared $99.9 \%$ sequence similarity of $16 \mathrm{~S}$ rDNA. Only one base difference at position 75 , a "G" in EriWB and an "A" in RPWB 16S rDNA, distinguished the 16S rDNAs of these strains. This difference may represent normal sequence variability existing within the population of Erigeron witches'-broom phytoplasma strains. The data are consistent with the concept that EriWB and RPWB are strains of the same phytoplasma species.

Because some of the RFLP patterns of 16S rDNA from Erigeron witches'-broom phytoplasma strains are similar to those from members of groups 16SrVI and 16 SrVII, further analyses were done to compare EriWB with known strains from those groups. Sequence similarities between 1.2-kbp sequences of $16 \mathrm{~S}$ rDNA (equivalent to fragments amplified in PCRs primed by $F 2 n / R 2$ ) from the EriWB phytoplasma and phytoplasmas affliliated with groups $16 \mathrm{SrVI}$ and $16 \mathrm{SrVII}$ were determined (Table 3 ). Sequence similarity with group $16 \mathrm{SrV}$ (elm yellows phytoplasma group) was also determined to afford comparisons with a third group.

EriWB shared $96.3 \%$ sequence similarity of $16 \mathrm{~S}$ rDNA with EY (EY1) phytoplasma (member of group $16 \mathrm{SrV}$ ). 16S rDNA sequence similarities between EriWB phytoplasma and two phytoplasma strains from group 16SrVI were 96.9 and $97.7 \%$. Sequence similarities between EriWB phytoplasma and four phytoplasmas strains from group $16 \mathrm{SrVII}$ ranged from 98.2 to $98.5 \%$. These data, combined with the coefficients of similarity, indicated that EriWB phytoplasma was most closely related to group VII strains among known phytoplasmas.

In classifying the Erigeron witches'broom phytoplasma, it was desirable to reflect its relatedness to strains previously classified in group VII, and to distinguish it from the subgroup VII-A phytoplasma strains from ash and lilac in North America. The sequence similarities between $16 \mathrm{~S}$ rDNAs of EriWB and AshY phytoplasma strains support the classification of Erigeron witches'-broom phytoplasma in group 16SrVII (ash yellows phytoplasma group) and the designation of strains EriWB and RPWB as representative of a new subgroup VII-B.

Erigeron witches'-broom phytoplasma 16S rDNA versus signature sequences of " $\boldsymbol{C a}$. P. fraxini". In the description of "Ca. P. fraxini", the AshY phytoplasma, two regions in the $16 \mathrm{~S}$ rRNA gene sequence were reported as signature sequences unique to this species (11). In spite of the clear distinction, noted above, of Erigeron witches'-broom phytoplasma from " $\mathrm{Ca}$. P. fraxini" on the basis of RFLP analysis and sequence similarity of $16 \mathrm{~S}$ rDNA, Erigeron witches'-broom phytoplasma contains one of the two " $\mathrm{Ca}$. $\mathrm{P}$. fraxini" signature sequences and differs from the second ' $C a$. P. fraxini' signature sequence by a single base substitution. The "Ca. P. fraxini" signature sequence 5 AGGAAAGTC-3', beginning at position 588 (11), is found in Erigeron witches'broom without base substitution. The " $\mathrm{Ca}$. P. fraxini" signature sequence beginning at position 66 is 5'-CGGAAACCCCTCAAA AGGTTT-3' (11). The corresponding sequence in EriWB phytoplasma is $5^{\prime}$ CGGAAACCCCTCAAGAGGTTT-3'.

Table 2. Similarity coefficients derived from restriction fragment length polymorphisms (RFLPs) based on putative restriction site analysis of nucleotide sequences of $16 \mathrm{~S}$ rDNA from Erigeron witches'-broom phytoplasma and other selected phytoplasmas

\begin{tabular}{|c|c|c|c|c|c|c|c|c|}
\hline Phytoplasma $^{a}$ & $\begin{array}{l}\text { 16S rRNA group } \\
\text { affiliation }^{\mathrm{b}}\end{array}$ & EriWB & $\operatorname{AshY1}^{\mathrm{T}}$ & AshY3 & AshY5 & LWB3 & $\mathbf{C P}$ & MC \\
\hline EriWB & VII-B & 1.00 & & & & & & \\
\hline AshY1 $1^{\mathrm{T}}$ & VII-A & 0.91 & 1.00 & & & & & \\
\hline AshY3 & VII-A & 0.94 & 0.97 & 1.00 & & & & \\
\hline AshY5 & VII-A & 0.91 & 1.00 & 0.97 & 1.00 & & & \\
\hline LWB3 & VII-A & 0.88 & 0.97 & 0.95 & 0.89 & 1.00 & & \\
\hline $\mathrm{CP}$ & VI-A & 0.89 & 0.84 & 0.86 & 0.86 & 0.83 & 1.00 & \\
\hline $\mathrm{MC}$ & VI-B & 0.86 & 0.81 & 0.84 & 0.83 & 0.80 & 0.94 & 1.00 \\
\hline
\end{tabular}

${ }^{\mathrm{a}}$ EriWB, Erigeron witches'-broom phytoplasma strain EriWB. AshY1 ${ }^{\mathrm{T}}$, AshY3, AshY5, and LWB3; strains of ash yellows phytoplasma, "Candidatus Phytoplasma fraxini". CP, clover proliferation phytoplasma. MC, "Fragaria multicipita" phytoplasma.

${ }^{\mathrm{b}}$ Groups are indicated in Roman numerals. Letters indicate subgroups. Designation of phytoplasma 16S rDNA group and subgroup affiliations are according to Lee et al. (18).

Table 3. Sequence similarities among $16 \mathrm{~S}$ rDNAs from Erigeron witches'-broom (EriWB) phytoplasma and previously described phytoplasma strains belonging to groups $16 \mathrm{SrVI}$ and $16 \mathrm{SrVII}$

\begin{tabular}{|c|c|c|c|c|c|c|c|c|}
\hline Phytoplasma $^{a}$ & $\begin{array}{l}\text { 16S rDNA group- } \\
\text { subgroup affiliation }\end{array}$ & EriWB & $\operatorname{AshY1}^{T}$ & AshY3 & AshY5 & LWB3 & $\mathbf{C P}$ & MC \\
\hline EriWB & VII-B & 100 & & & & & & \\
\hline AshY1 $1^{\mathrm{T}}$ & VII-A & 98.5 & 100 & & & & & \\
\hline AshY3 & VII-A & 98.5 & 99.8 & 100 & & & & \\
\hline AshY5 & VII-A & 98.5 & 100 & 99.8 & 100 & & & \\
\hline LWB3 & VII-A & 98.2 & 99.7 & 99.5 & 99.7 & 100 & & \\
\hline $\mathrm{CP}$ & VI-A & 97.7 & 97.0 & 97.0 & 97.0 & 96.7 & 100 & \\
\hline MC & VI-B & 96.9 & 96.6 & 96.6 & 96.6 & 96.3 & 99.0 & 100 \\
\hline
\end{tabular}

${ }^{a}$ EriWB, Erigeron witches'-broom phytoplasma strain EriWB. AshY1 ${ }^{\mathrm{T}}$, AshY3, AshY5, and LWB3; strains of ash yellows phytoplasma, "Candidatus Phytoplasma fraxini". CP, clover proliferation phytoplasma. MC, "Fragaria multicipita" phytoplasma.

${ }^{\mathrm{b}}$ Roman numerals indicate 16S rDNA groups. Subgroups are indicated by letters. Designation of group and subgroup affiliations are according to Lee et al. (18). 
These findings emphasize the close relationship of EriWB phytoplasma to ash yellows and lilac witches'-broom phytoplasmas classified in group VII.

Phylogenetic analysis. Phylogenetic analysis of 16S rRNA gene sequences from 26 phytoplasma strains and A. laidlawii yielded a tree whose branching order is in general agreement with previous findings $(5,11,18,19)$ (Fig. 3). Erigeron witches'- broom phytoplasma emerges as a new branch, not seen in previous phylogenetic trees. The branching order indicates that ash yellows, lilac witches'-broom, and Erigeron witches'-broom phytoplasmas descended from a common ancestor. The branching also indicates that EriWB phytoplasma represents a new lineage, supporting the distinction of this phytoplasma from ash yellows phytoplasma strains previously described as strains of "Ca. P. fraxini".

\section{DISCUSSION}

In this communication, we describe the discovery in Brazil of a new member of the ash yellows phytoplasma group, group 16SrVII. We have placed the Erigeron witches'-broom phytoplasma in a new subgroup (VII-B) of group 16SrVII, indi-

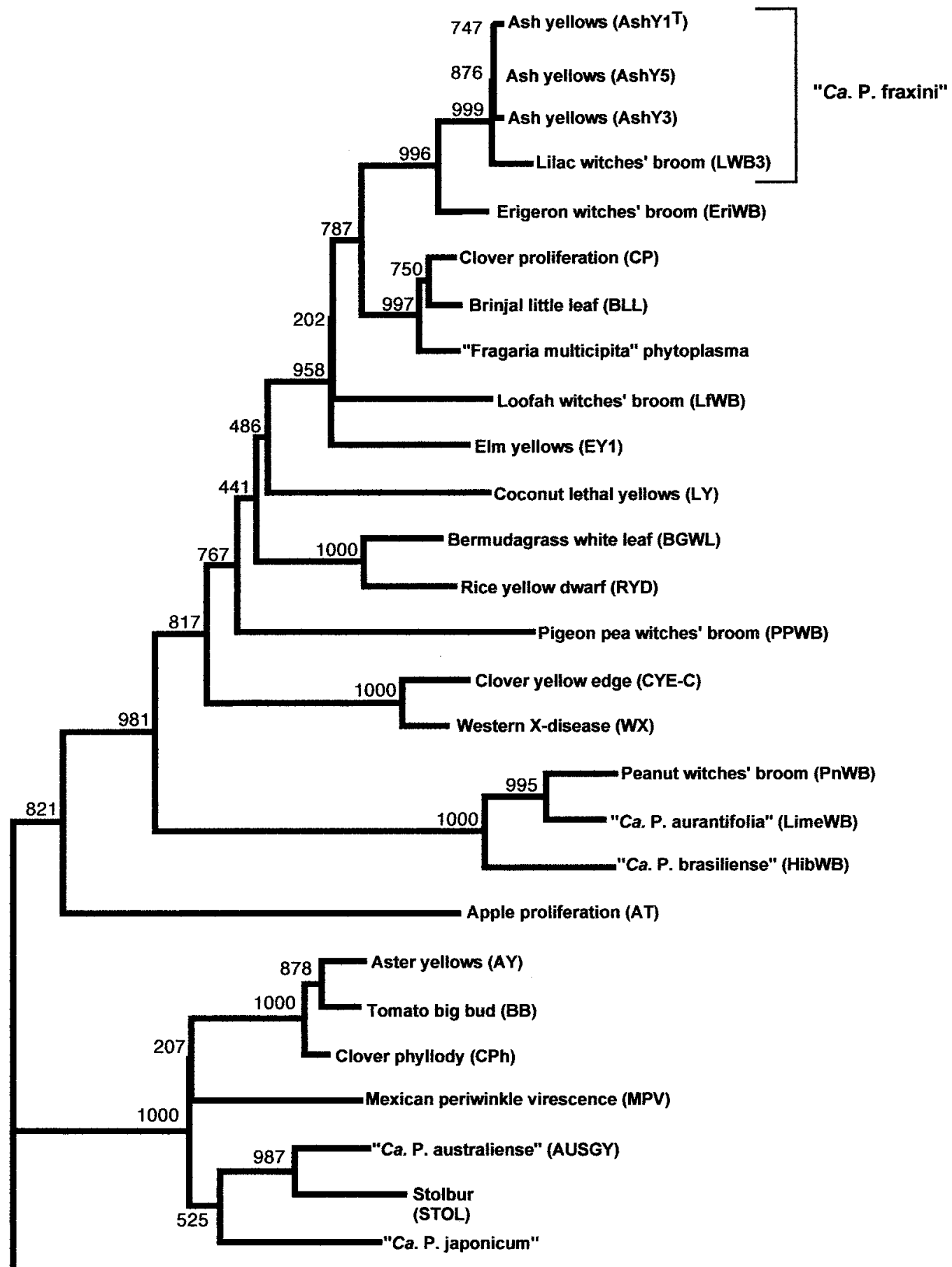

Fig. 3. Phylogenetic tree constructed by the Neighbor-Joining method of 16S rRNA gene sequences from 27 phytoplasmas and Acholeplasma laidlawii, employing A. laidlawii as the outgroup. The numbers on the branches are bootstrap (confidence) values. Phytoplasma strain designations are in parentheses. 
cating that it possesses unique properties that are reflected in the results from enzymatic RFLP analyses, sequence similarities, coefficients of similarity, and phylogenetic analysis based on 16S rRNA gene sequences. Phytoplasmas previously described in Brazil belong to four distinct phylogenetic groups: the aster yellows phytoplasma group (16SrI) (2,7), the Xdisease phytoplasma group (16SrIII) $(1,7,23)$, the pigeon pea witches'-broom phytoplasma group (16SrIX) (3), and the hibiscus witches'-broom group (16SrXV) (22). Erigeron witches'-broom phytoplasma is the first of the ash yellows phytoplasma group (group 16SrVII) to be reported in Brazil.

The present study and other work recently published in abstract form are the first to report members of the ash yellows phytoplasma group outside of North America $(8,21$; this paper). Previously, ash yellows has been a disease known only on the North American continent, where it is apparently restricted to species of Syringa and Fraxinus, members of the family Oleaceae $(11,31,32)$. These two genera do not occur naturally in Brazil, but Fraxinus is cultivated as an ornamental in some regions. Other genera in the Oleaceae, including Linociera and Chionantus, are native to South America, and it would be of interest to learn whether these latter genera may be infected by Erigeron witches'-broom or other phytoplasmas affiliated with group 16SrVII (group VII). Griffiths et al. (8) reported ash yellows disease in Fraxinus chinensis in Columbia, and Meneguzzi et al. (21) reported a group VII phytoplasma in diseased alfalfa in Argentina, but nucleotide sequences of the phytoplasmas' 16S rRNA genes were not reported. It would be interesting to know the relationships among group VII phytoplasmas in Columbia (8) and Argentina (21), ash yellows phytoplasma strains in North America (11), and Erigeron witches'-broom phytoplasma in Brazil (this study).

More than 200 species of Erigeron are known on the North American continent, where they are widespread. Although Erigeron sp. is not native to Brazil, the genus now is widespread and adapted to local ecological conditions in Brazil. Species of Erigeron were first described as hosts of phytoplasmas in Brazil by Kitajima and Costa $(15,16)$, on the basis of phytoplasma-characteristic disease symptoms in plants and the observation of phytoplasma cells in phloem of diseased plants examined by electron microscopy. In addition to group VII phytoplasma strains reported in the present study, an undescribed phytoplasma belonging to group 16SrI (aster yellows phytoplasma group) has been reported in plants of Erigeron bonariensis with symptoms of witches'-broom (4). Thus, it is apparent that species of Erigeron may serve as hosts for divergent phy- toplasma lineages in Brazil. The presence of Erigeron witches'-broom phytoplasma strains in both Erigeron sp. and periwinkle plants, as shown in the present study, suggests that at least one polyphagous insect is capable of transmitting this phytoplasma in Brazil. This raises the possibility that other, as yet undiscovered, plant hosts of group VII phytoplasma strains exist in South America.

To date, 15 major groups and over 34 subgroups of phytoplasmas have been reported. Each major group represents at least one species (22); the appropriate taxonomic rank of many recognized subgroups is not yet clear (18). Because it is not possible to obtain phytoplasmas in pure culture in vitro, a provisional system of naming distinct phytoplasmas as "Candidatus Phytoplasma species" has been adopted, and several such species have been distinguished and described principally on the basis of results from analysis of $16 \mathrm{~S}$ rRNA gene sequences $(6,11,22,28,35,36)$. For example, group $16 \mathrm{SrVII}$ (ash yellows phytoplasma group) was designated "Candidatus Phytoplasma fraxini” (11). Although Erigeron witches'broom phytoplasma is a member of group $16 \mathrm{SrVII}$, data in the present study clearly indicate that it represents a subgroup distinct from strains presently encompassed in this species. Conceivably, ecological and/or geographical isolation could have fostered evolutionary divergence of Erigeron witches'-broom phytoplasma from its closest known relatives. Yet it is not clear that this distinction is of species level character, particularly because Erigeron witches'-broom phytoplasma and " $C a$. $\mathrm{P}$. fraxini" strains share a $16 \mathrm{~S}$ rDNA sequence similarity that is greater than the current species level threshold of $97.5 \%$, and Erigeron witches'-broom phytoplasma contains 16S rDNA signature sequences reported for " $\mathrm{Ca}$. P. fraxini" (this paper). Further work is needed to assess the taxonomic significance of $16 \mathrm{~S}$ rRNA gene sequence divergence and other properties of Erigeron witches'-broom phytoplasma in order to determine whether it represents a distinct "Candidatus Phytoplasma species".

\section{ACKNOWLEDGMENTS}

We thank Jim Plaskowitz for help in preparing figures in this manuscript and Rasa Jomantiene for helpful suggestions during the writing of the manuscript.

\section{LITERATURE CITED}

1. Barros, T. S. L., Kitajima, E. W., and Resende, R. O. 1998. Divergence of Brasilian phytoplasmas based on analyses of $16 \mathrm{~S}$ rDNA. Fitopatol. Bras. 23:459-465.

2. Bedendo, I. P., Davis, R. E., and Dally, E. L. 1997. Molecular evidence for the presence of maize bushy stunt phytoplasma in corn in Brazil. Plant Dis. 81:957.

3. Bedendo, I. P., Davis, R. E., and Dally, E. L. 1999. Detecção e caracterização de fitoplasmas em plantas de vinca (Catharanthus roseus) e de pimenta (Capsicum frustescens) através das técnicas de duplo PCR e de RFLP. Summa Phytopathol. 25:197-201.

4. Bianchini, L., and Bedendo, I. P. 2000. Presença de um fitoplasma do grupo I, evidenciado por PCR, em plantas de Erigeron (Erigeron bonariensis) com superbrotamento. (Abstr.) Fitopatol. Bras. 25:348

5. Davis, R. E., and Dally, E. L. 2001. Revised subgroup classification of group $16 \mathrm{SrV}$ phytoplasmas and placement of flavescence dorée-associated phytoplasmas in two distinct subgroups. Plant Dis. 85:790-797.

6. Davis, R. E., Dally, E. L., Gundersen, D. E., Lee, I.-M., and Habili, N. 1997. "Candidatus Phytoplasma australiense," a new phytoplasma taxon associated with australian grapevine yellows. Int. J. Syst. Bacteriol. 47:262-269.

7. Davis, R. E., Dally, E. L., Lee, I.-M., Resende, R. O., and Kitajima, E. W. 1994. Detection and characterization of mycoplasmalike organisms (MLOs) in diverse plant species in Brazil. (Abstr.) Fitopatol. Bras. 19:340.

8. Griffiths, H. M., Boa, E. R., and Filgueira, J. J. 2001. Ash yellows: A new disease of Fraxinus chinensis in Columbia. (Abstr.) Phytopathology 91:S32-33.

9. Griffiths, H. M., Sinclair, W. A., BoudonPadieu, E., Daire, X., Lee, I.-M., Sfalanga, A., and Bertaccini, A. 1999. Phytoplasmas associated with elm yellows: Molecular variability and differentiation from related organisms. Plant Dis. 83:1101-1104.

10. Griffiths, H. M., Sinclair, W. A., Davis, R. E., Lee, I.-M., Dally, E. L., Guo, Y.-H., Chen, T. A., and Hibben, C. R. 1994. Characterization of mycoplasmalike organisms from Fraxinus, Syringa, and associated plants from geographically diverse sites. Phytopathology 84:119-126.

11. Griffiths, H. M., Sinclair, W. A., Smart, C. D., and Davis, R. E. 1999. The phytoplasma associated with ash yellows and lilac witches' broom: 'Candidatus Phytoplasma fraxini'. Int. J. Syst. Bacteriol. 49:1605-1614.

12. Gundersen, D. E., and Lee, I.-M. 1996. Ultrasensitive detection of phytoplasmas by nested-PCR assays using two universal primer pairs. Phytopathol. Mediterr. 35:144-151.

13. Gundersen, D. E., Lee, I.-M., Rehner, S. A., Davis, R. E., and Kingsbury, D. T. 1994. Phylogeny of mycoplasmalike organisms (phytoplasmas): A basis for their classification. $\mathrm{J}$. Bacteriol. 176:5244-5254.

14. Jomantiene, R., Davis, R. E., Maas, J., and Dally, E. L. 1998. Classification of new phytoplasmas associated with diseases of strawberry in Florida, based on analysis of $16 \mathrm{~S}$ rRNA and ribosomal protein gene operon sequences. Int. J. Syst. Bacteriol. 48:269-277.

15. Kitajima, E. W., and Costa, A. S. 1970. Micoplasma, possível agente etiológico de certas moléstias de plantas. Ciência Cultura 22:351363.

16. Kitajima, E. W., and Costa, A. S. 1979. Microorganismos do tipo micoplasma associados a moléstias do tipo amarelo em algumas plantas cultivadas e ornamentais, no estado de São Paulo e no Distrito Federal. Fitopatol. Bras. 4:317-327.

17. Lee, I.-M., Davis, R. E., and GundersenRindal, D. E. 2000. Phytoplasma: Phytopathogenic mollicutes. Annu. Rev. Microbiol. 54:221-255.

18. Lee, I.-M., Gundersen-Rindal, D. E., Davis, R. E., and Bartoszyk, I. M. 1998. Revised classification scheme of phytoplasmas based on RFLP analyses of 16S rRNA and ribosomal protein gene sequences. Int. J. Syst. Bacteriol. 48:1153-1169.

19. Lee, I.-M., Hammond, R. W., Davis, R. E., and Gundersen, D. E. 1993. Universal ampli- 
fication and analysis of pathogen $16 \mathrm{~S}$ rDNA for classification and identification of mycoplasmalike organisms. Phytopathology 83:834-842.

20. Lim, P.-O., and Sears, B. B. 1989. 16S rRNA sequence indicates that plant-pathogenic mycoplasmalike organisms are evolutionarily distinct from animal mycoplasmas. J. Bacteriol. 171:5901-5906.

21. Meneguzzi, N., Torres, L., Galdeano, E., Nome, C., Docampo, D., Nome, S., and Conci, L. 2001. Phylogenetic analysis of an ash yellows group phytoplasma detected in alfalfa (Medicago sativa L.), in Argentina. (Abstr.) Fitopatol. Bras. 26(Supl.):510.

22. Montano, H. G., Davis, R. E., Dally, E. L., Hogenhout, S., Pimentel, J. P., and Brioso, P. S. T. 2001. 'Candidatus Phytoplasma brasiliense', a new phytoplasma taxon associated with hibiscus witches' broom disease. Int. J. Syst. Evol. Microbiol. 51:1109-1118.

23. Montano, H. G., Davis, R. E., Dally, E. L., Pimentel, J. P., and Brioso, P. S. T. 2000. Identification and phylogenetic analysis of a new phytoplasma from diseased chayote in Brazil. Plant Dis. 84:429-436.

24. Namba, S., Oyaizu, H., Kato, S., Iwanami, S., and Tsuchizaki, T. 1993. Phylogenetic diversity of phytopathogenic mycoplasma-like organisms. Int. J. Syst. Bacteriol. 43:461-467.

25. Nei, M., and Li, W.-H. 1979. Mathematical model for studying genetic variation in terms of restriction endonucleases. Proc. Natl. Acad. Sci. USA 76:5269-5273.
26. Page, R. D. 1996. TreeView: An application to display phylogenetic trees on personal computers. Comput. Appl. Biosci. 12:357358.

27. Prince, J. P., Davis, R. E., Wolf, T. K., Lee, I.M., Mogen, B. D., Dally, E. L., Bertaccini, A., Credi, R., and Barba, M. 1993. Molecular detection of diverse mycoplasmalike organisms (MLOs) associated with grapevine yellows and their classification with aster yellows, Xdisease, and elm yellows MLOs. Phytopathology 83:1130-1137.

28. Sawayanagi, T., Horikoshi, N., Kanehira, T., Shinohara, M., Bertaccini, A., Cousin, M. T., Hiruki, C., and Namba, S. 1999. 'Candidatus Phytoplasma japonicum', a new phytoplasma taxon associated with Japanese hydrangea phyllody. Int. J. Syst. Bacteriol. 49:12751285.

29. Schneider, B., Cousins, M. T., Klinkong, S., and Seemüller, E. 1995. Taxonomic relatedness and phylogenetic position of phytoplasmas associated with diseases of faba bean, sunnhemp, sesame, soybean, and eggplant. Z. Pflanzenkrankh. Pflanzenschutz 102:225-232.

30. Seemüller, E., Schneider, B., Mäurer, R., Ahrens, U., Daire, X., Kison, H., Lorenz, K. H., Firrao, G., Avinent, L., and Sears, B. B. 1994. Phylogenetic classification of phytopathogenic mollicutes by sequence analysis of 16 S ribosomal DNA. Int. J. Syst. Bacteriol. 44:440-446.

31. Sinclair, W. A., and Griffiths, H. M. 2000. Variation in aggressiveness of ash yellows phytoplasmas. Plant Dis. 84:282-288.

32. Sinclair, W. A., Griffiths, H. M., and Davis, R. E. 1996. Ash yellows and lilac witches'broom: Phytoplasmal diseases of concern in forestry and horticulture. Plant Dis. 80:468475.

33. Smart, C. D., Schneider, B., Blomquist, C. L. Guerra, L. J., Harrison, N. A., Ahrens, U., Lorenz, K.-H., Seemüller, E., and Kirkpatrick, B. C. 1996. Phytoplasma-specific PCR primers based on sequences of the $16 \mathrm{~S}-23 \mathrm{~S}$ spacer region. Appl. Environ. Microbiol. 62:29882993.

34. Thompson, J. D., Gibson, T. J., Plewniak, F., Jeanmougin, F., and Higgins, D. G. 1997. The Clustal X windows interface: Flexible strategies for multiple sequence alignment aided by quality analysis tools. Nucleic Acids Res. 25:4876-4882.

35. White, D. T., Blackall, L. L., Scott, P. T., and Walsh, K. B. 1998. Phylogenetic positions of phytoplasmas associated with dieback, yellow crinkle and mosaic diseases of papaya, and their proposed inclusion in 'Candidatus Phytoplasma australiense' and a new taxon, 'Candidatus Phytoplasma australasia'. Int. J. Syst. Bacteriol. 48:941-951.

36. Zreik, L., Carle, P., Bové, J. M., and Garnier, M. 1995. Characterization of the mycoplasmalike organism associated with witches'broom disease of lime and proposition of a Candidatus taxon for the organism, "Candidatus Phytoplasma aurantifolia”. Int. J. Syst. Bacteriol. 45:449-453. 